\title{
A statistical approach to evaluate the chemistry and quality of groundwater in Jamankira area, Sambalpur district, Orissa, India
}

\author{
*J. K. Jena ${ }^{l}$, P. K. Verma ${ }^{l}$, and H. K. Sahoo ${ }^{2}$ \\ ${ }^{1}$ School of Studies in Geology, Vikram University, \\ Ujjain, M.P. 456010 \\ ${ }^{2}$ Department of Earth Science, Sambalpur University, \\ Jyoti Vihar, Burla, Orissa \\ (*Email: jayantakumarjena@rediffmail.com)
}

\begin{abstract}
The groundwater quality in the Jamankira area of Sambalpur district was evaluated to determine its hydrogeochemical variability. A total of thirty groundwater samples were analysed for their major chemical constituents. The quality of groundwater was estimated on the basis of total dissolved solids, sodium adsorption ratio, sodium percentage, residual sodium carbonate, and Piper's trilinear diagram. Cluster analysis was used in the study as a qualitative means for differentiating the groundwater into distinctive types. The cluster analysis shows: 1) $\mathrm{Ca}-\mathrm{HCO}_{3}-\mathrm{SO}_{4}-\mathrm{Mg}$ bearing calcium-rich water and 2) $\mathrm{Na}-\mathrm{K}-\mathrm{Cl}$ bearing sodium-rich water in the study area.
\end{abstract}

\section{INTRODUCTION}

There is an increasing dependency on groundwater for sustainable development. Population explosion, enhanced urbanisation, and industrialisation as well as modernising agriculture have put tremendous pressure on the available and known groundwater resources. As a result, there is a significant depletion in groundwater resources evidenced by widespread deepening of the water table. Water plays a vital role in our life, as it is indispensable not only for sustenance but also in determining the quality of life. Groundwater is a renewable natural resource replenished annually by precipitation. Water is also one of the natural transport media of several essential minerals, which affect human life as well as vegetation. Hence the knowledge of the constituents dissolved in water is important to ascertain its quality for domestic and irrigation purposes. Many countries in the world are now conducting irrigation development programmes based on groundwater resources. Groundwater quality is one of the important parameters of concern for implementation of such programmes. In this perspective, this paper deals with the groundwater quality in the Jamankira area of Sambalpur district, Orissa, India.

\section{STUDYAREA}

The town of Jamankira is situated at a distance of $65 \mathrm{~km}$ from Sambalpur on the eastern margin of the Sambalpur district (Fig. 1). The study area lies between latitude 21 $30^{\prime}-$ $21^{\circ} 39^{\prime} \mathrm{N}$ and longitude $84^{\circ} 18^{\prime}-84^{\circ} 26^{\prime} \mathrm{E}$ (survey of India topographic map no. $73 \mathrm{C} / 6$ ) and covers an area of approximately $234 \mathrm{sq} \mathrm{km}$. This area is selected due to its varied geological and geomorphological characteristics and unmitigated water requirement of large population inhabiting the region.

The area is mainly covered by Eastern Ghat Group of rocks (granites and gneisses) intruded by NW-SE trending dolerite dykes. In general, the granitic rocks along with dolerite, hornblende schist, and chlorite-biotite gneiss occupy the Jamankira area. Laterites of Recent age are present at some places (Wadia 1957; GSI 1979).

\section{GROUNDWATER QUALITY}

In groundwater resource evaluation, quality is as important as quantity. The quality of water determines its suitability for domestic, irrigation, or industrial use. Thirty water samples (twenty from dug wells and ten from bore wells) were collected from the study area and analysed for groundwater quality estimation (Table 1).

The concentration of total dissolved solids (TDS) in the groundwater of the study area varies between 89 and 451 ppm, and thus the water can be classified as non-saline. The sodium adsorption ratio (SAR) of the groundwater samples varies from 0.25 to 1.04 epm (within permissible limits) with an average of 0.487 epm (sodium-rich water) and hence the water is excellent for irrigation purposes. The plot of SAR on an arithmetical scale against the electrical conductivity (EC) on a log scale (Fig. 2) indicates that $27 \%$ of water samples fall in $\mathrm{C}_{1} \mathrm{~S}_{1}$ class, $60 \%$ of water samples fall in $\mathrm{C}_{2} \mathrm{~S}_{1}$ class, and remaining $13 \%$ of them lie in $\mathrm{C}_{3} \mathrm{~S}_{1}$ class. The sodium percentage (SP) in terms of epm of the common cations was 


\section{J. K. Jena et al.}

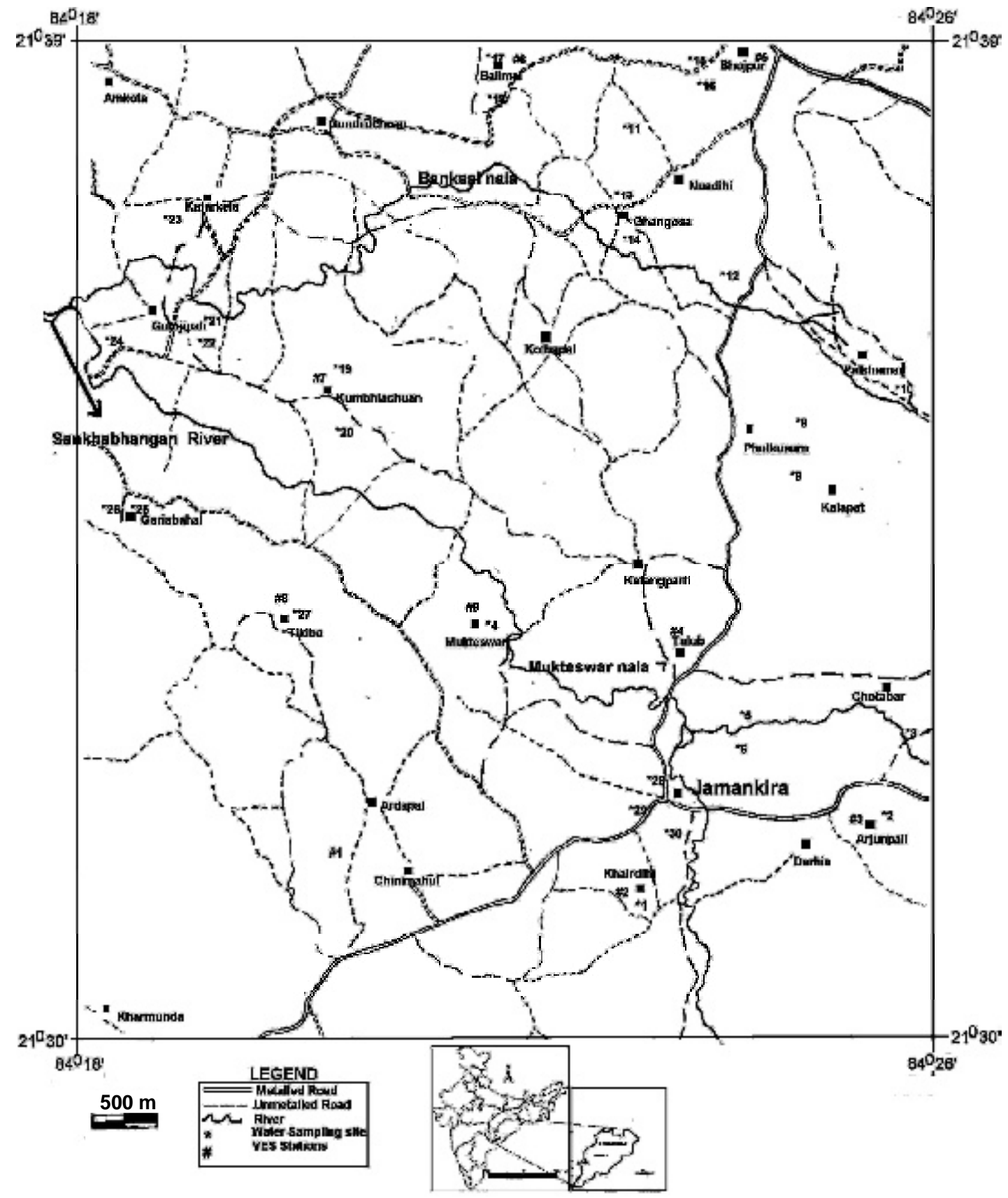

Fig. 1: Location map of the study area

defined by Wilcox $(1948)$ as Na percentage $=\left\{\left(\mathrm{Na}^{+}+\mathrm{K}^{+}\right) /\right.$ $\left.\left(\mathrm{Ca}^{2+}+\mathrm{Mg}^{2+}+\mathrm{Na}^{+}+\mathrm{K}^{+}\right)\right\}^{*} 100$. The groundwater samples of the study area have a sodium percentage value of 10.06 to 37.13 (excellent to good for irrigation purposes). The SP values plotted against EC values (Fig. 3) also indicate the suitability of water for irrigation purposes.

When carbonate concentration in irrigation water is higher than the alkaline earth metals, the remaining part of $\mathrm{HCO}_{3}^{-}$, which is left after precipitation of alkaline earth carbonates, combines with sodium to form a highly soluble carbonate known as residual sodium carbonate (RSC). RSC (in epm $)=\left(\mathrm{HCO}_{3}^{-}+\mathrm{CO}_{3}{ }^{2-}\right)-\left(\mathrm{Ca}^{2+}+\mathrm{Mg}^{2+}\right)$ and, is called Eaton's Index (1950). The water with RSC content below 1.25 epm is safe, between 1.25 and 2.5 epm is marginal, and above $2.5 \mathrm{epm}$ is not suitable for irrigation purposes. The excessive RSC content causes the soil structure to deteriorate, as water and air movement through soil is restricted. The samples in the present study area have shown negative values for RSC indicating that the water is quite safe for irrigation. 


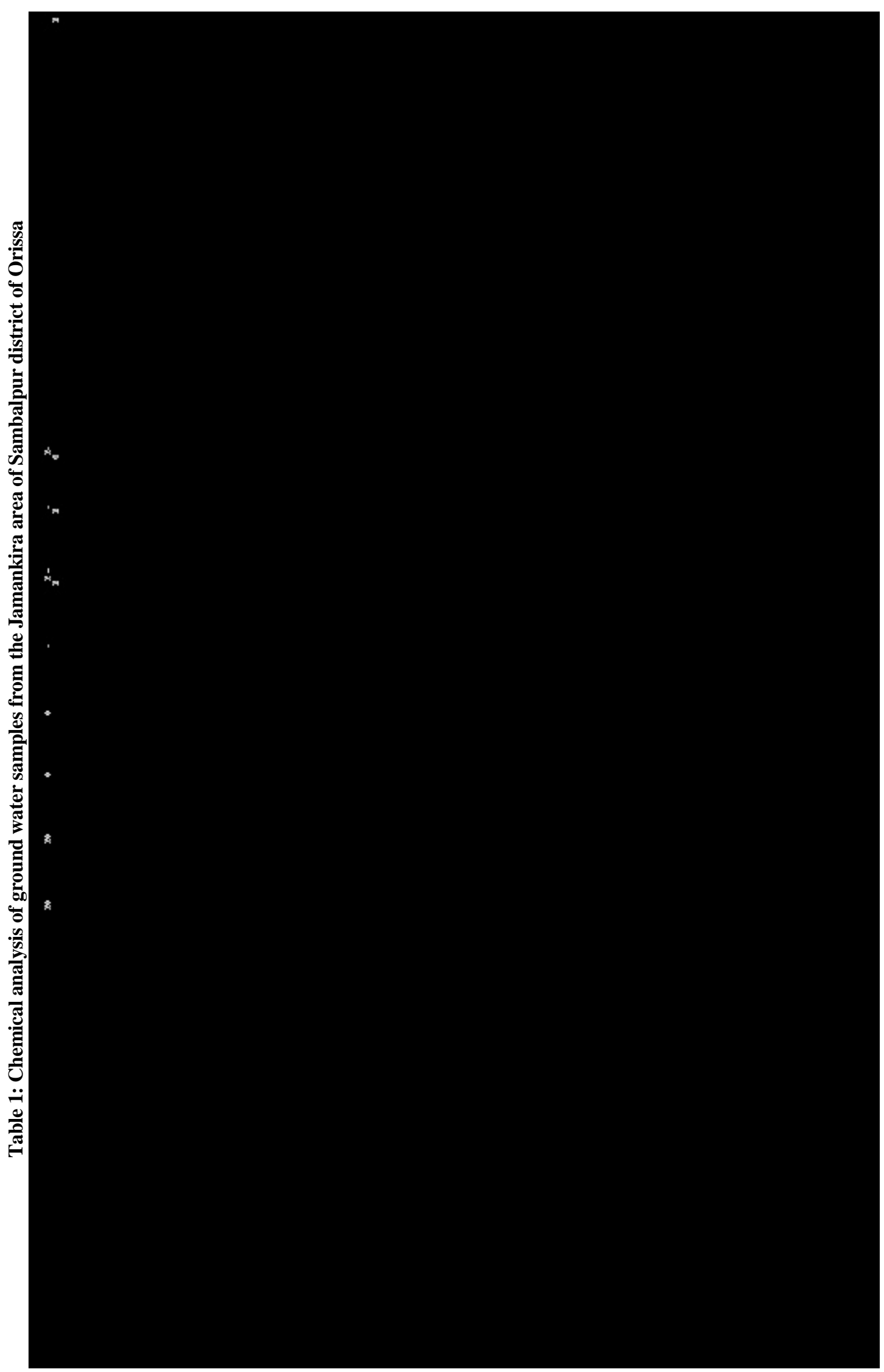




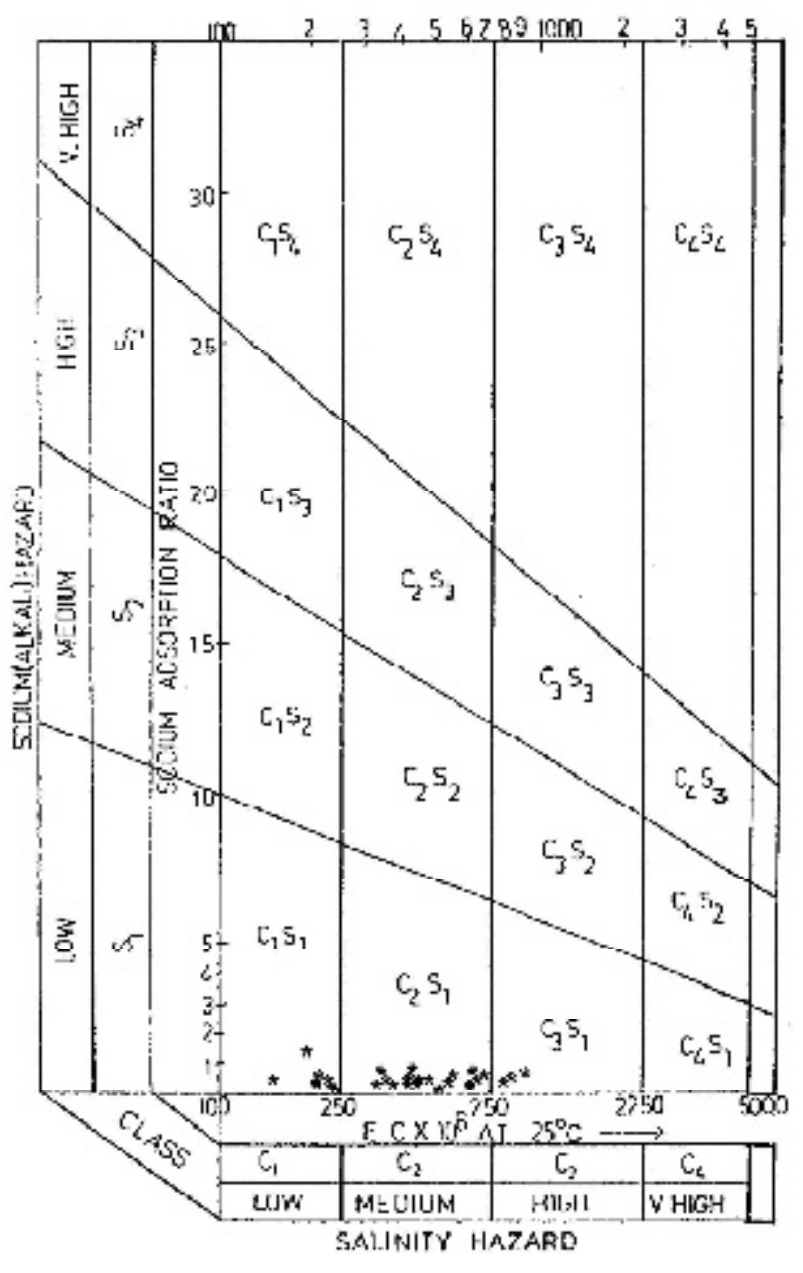

Fig. 2: Data plotted in the U. S. salinity diagram (Richards 1954).

The Trilinear Piper's diagram (Piper 1944) is widely used to represent the chemical analysis data and forms a basis for classification natural waters for drinking applications. The diagram was prepared for the Jamankira area (Fig. 4) where, based on the domination of different cation and anion groups, three distinct hydrochemical facies were identified (Fig. 5).

Facies $1\left(\mathrm{Na}^{+}-\mathrm{K}^{+}-\mathrm{Cl}^{-}-\mathrm{SO}_{4}{ }^{2-}\right)$ : The eleven samples belong to this facies. This facies is dominated by "alkalies" and "strong acids". In this type of water, $\mathrm{K}^{+}$is characterised by its excessive presence.

Facies $2\left(\mathrm{Ca}^{2+}-\mathrm{Mg}^{2+}-\mathrm{Cl}^{-}-\mathrm{SO}_{4}^{2-}\right)$ : The eleven samples belong to this facies. This facies is dominated by $\mathrm{Cl}^{-}$and alkaline earths. In this type of water $\mathrm{SO}_{4}^{-}$is characterised by its enhanced presence.

Facies $3\left(\mathrm{Na}^{+}-\mathrm{K}^{+}-\mathrm{HCO}_{3}^{-}\right)$: The seven samples belong to this facies. Groundwater of this group is characterised with a clear dominance of "alkalies" and "weak acids".

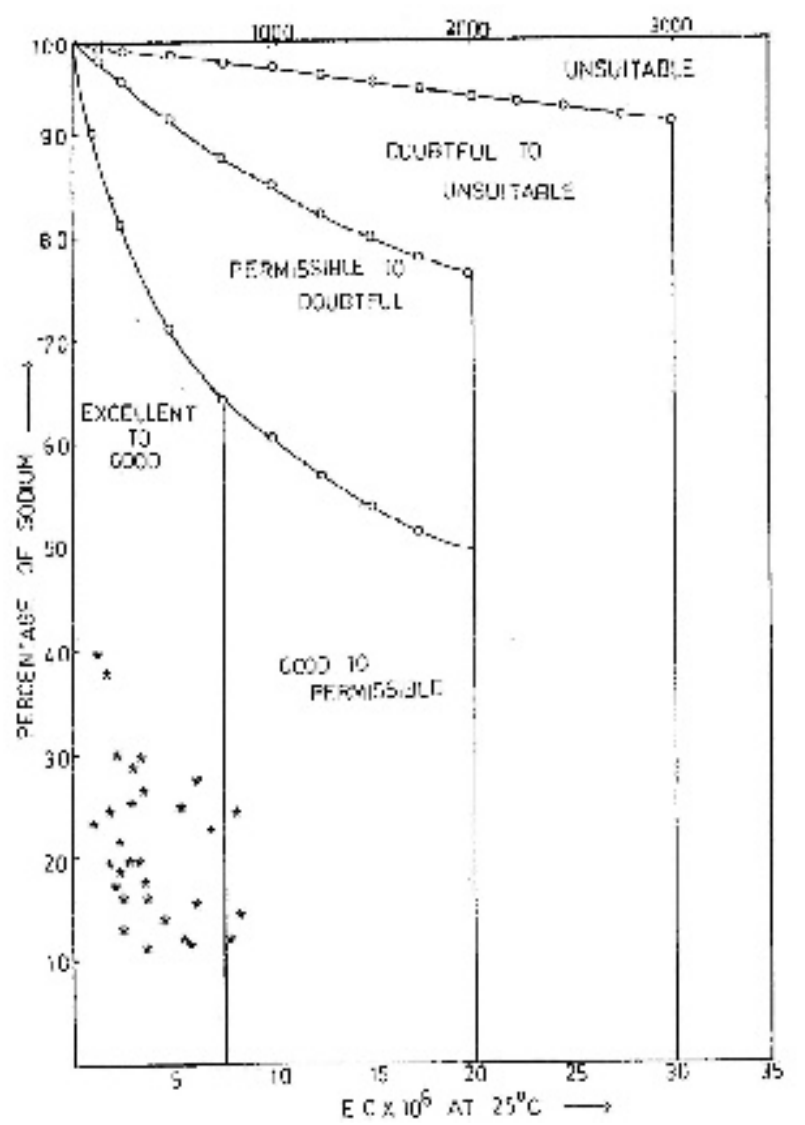

Fig. 3: Data plotted on the diagram (Wilcox, 1948) of $\mathrm{Na} \%$ against $E C$ values.

In general, from the Piper's diagram it is clear that there are two types of water in the study area such as sodium-rich water and calcium-rich water.

\section{Cluster analysis}

Cluster analysis (James 1966) is a method, which correlates a similar pair of relationships in a large symmetric matrix. This method is applied to reduce and organise a large data set into groups possessing similar attributes. Clustering brings forth a straightforward, logical, and pair-wise comparison between several chemical constituents. The results of cluster analysis in the present study are depicted in a dendrogram (Fig. 6). This is a two-dimensional hierarchical diagram, which clearly represents the similarity or dissimilarity between or among the coexisting groups.

Accordingly, the seven major variables in the form of cations and anions (viz. $\mathrm{Ca}^{2+}, \mathrm{Mg}^{2+}, \mathrm{Na}^{+}+\mathrm{K}^{+}, \mathrm{CO}_{3}{ }^{2-}, \mathrm{HCO}_{3}^{-}$, $\mathrm{Cl}^{-}, \mathrm{SO}_{4}^{2-}$ ) were determined (Table 1). By applying simple arithmetic averaging, correlation coefficient matrices obtained were further modified to carry out the cluster analysis (Davis 1973) for the seven variables. Based on them, a 7 x 7 correlation coefficient matrix was computed (Table 2a). In the first step of the cluster analysis, the highest 


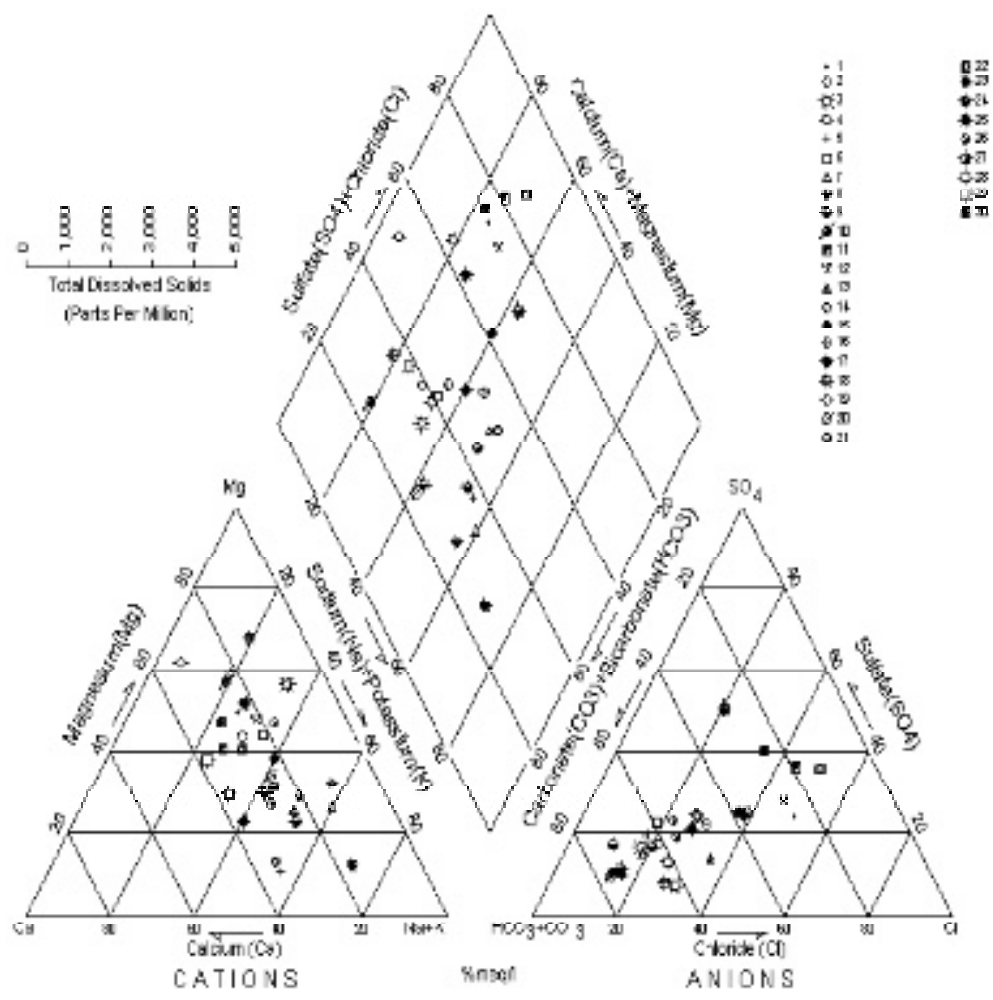

Fig. 4: Trilinear Piper diagram

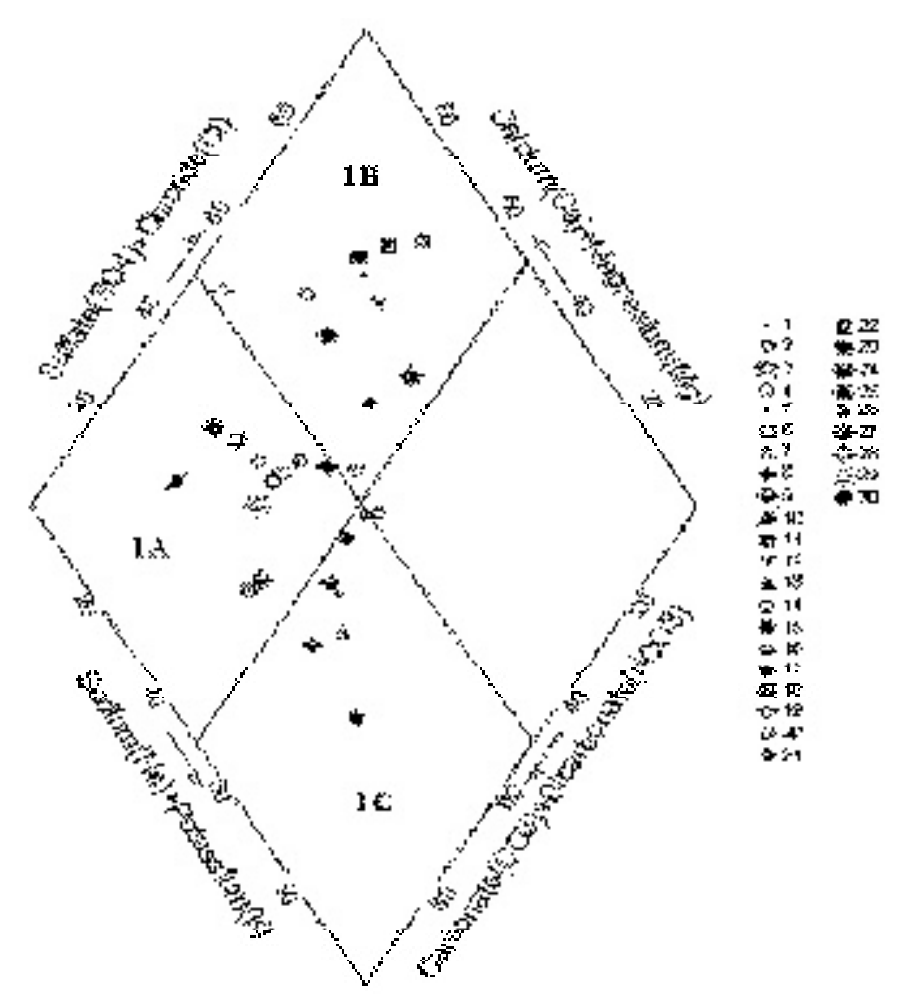

Fig. 5: Distribution of ground water samples in the Piper diagram 
Table 2a: First-step correlation matrix

\begin{tabular}{c|c|c|c|c|c|c|c}
\hline & $\mathrm{Ca}$ & $\mathrm{Mg}$ & $\mathrm{Na}+\mathrm{K}$ & $\mathrm{HCO}_{3}$ & $\mathrm{CO}_{3}$ & $\mathrm{Cl}$ & $\mathrm{SO}_{4}$ \\
\hline $\mathrm{Ca}$ & 1.000 & 0.623 & 0.437 & 0.822 & 0.351 & 0.449 & 0.721 \\
\hline $\mathrm{Mg}$ & 0.623 & 1.000 & 0.369 & 0.707 & -0.179 & 0.493 & 0.575 \\
\hline $\mathrm{Na}+\mathrm{K}$ & 0.437 & 0.369 & 1.000 & 0.599 & -0.068 & 0.495 & 0.643 \\
\hline $\mathrm{HCO}_{3}$ & 0.822 & 0.707 & 0.599 & 1.000 & -0.190 & 0.362 & 0.821 \\
\hline $\mathrm{CO}_{3}$ & -0.351 & -0.179 & -0.068 & -0.190 & 1.000 & -0.292 & -0.302 \\
\hline $\mathrm{Cl}$ & 0.449 & 0.493 & 0.495 & 0.362 & -0.292 & 1.000 & 0.386 \\
\hline $\mathrm{SO}_{4}$ & 0.721 & 0.575 & 0.643 & 0.821 & -0.302 & 0.386 & 1.000 \\
\hline
\end{tabular}

Table 2b: Second-step correlation matrix

\begin{tabular}{c|c|c|c|c|c|c}
\hline & $\mathbf{C a}-\mathbf{H C O}_{\mathbf{3}}$ & $\mathbf{M g}$ & $\mathbf{N a}+\mathbf{K}$ & $\mathbf{C O}_{\mathbf{3}}$ & $\mathbf{C l}$ & $\mathbf{S O}_{4}$ \\
\hline $\mathrm{Ca}-\mathrm{HCO}_{\mathbf{3}}$ & 1.000 & $\mathbf{0 . 6 6 5}$ & 0.518 & -0.27 & 0.405 & $\mathbf{0 . 7 7 1}$ \\
\hline $\mathrm{Mg}$ & $\mathbf{0 . 6 6 5}$ & $\mathbf{1 . 0 0 0}$ & $\mathbf{0 . 3 6 9}$ & $\mathbf{- 0 . 1 7 9}$ & $\mathbf{0 . 4 9 3}$ & $\mathbf{0 . 5 7 5}$ \\
\hline $\mathbf{N a}+\mathbf{K}$ & 0.518 & 0.369 & 1.000 & $\mathbf{- 0 . 0 6 8}$ & $\mathbf{0 . 4 9 5}$ & 0.643 \\
\hline $\mathbf{C O}_{3}$ & -0.27 & -0.179 & -0.068 & 1.000 & -0.292 & -0.302 \\
\hline $\mathrm{Cl}$ & 0.405 & 0.493 & 0.495 & -0.292 & 1.000 & 0.386 \\
\hline $\mathbf{S O}_{\mathbf{4}}$ & $\mathbf{0 . 7 7 1}$ & 0.575 & $\mathbf{0 . 6 4 3}$ & -0.302 & 0.386 & 1.000 \\
\hline
\end{tabular}

Table 2c: Third-step correlation matrix

\begin{tabular}{c|c|c|c|c|c}
\hline & $\mathrm{Ca}-\mathrm{HCO}_{3}-\mathbf{S O}_{4}$ & $\mathbf{M g}$ & $\mathbf{N a}+\mathrm{K}$ & $\mathbf{C O}_{3}$ & $\mathbf{C l}$ \\
\hline $\mathrm{Ca}-\mathrm{HCO}_{3}-\mathrm{SO}_{4}$ & 1.000 & $\mathbf{0 . 6 2}$ & $\mathbf{0 . 5 8}$ & -0.286 & 0.395 \\
\hline $\mathrm{Mg}$ & 0.62 & $\mathbf{1 . 0 0 0}$ & $\mathbf{0 . 3 6 9}$ & $\mathbf{- 0 . 1 7 9}$ & $\mathbf{0 . 4 9 3}$ \\
\hline $\mathbf{N a}+\mathrm{K}$ & 0.58 & 0.369 & 1.000 & $\mathbf{- 0 . 0 6 8}$ & $\mathbf{0 . 4 9 5}$ \\
\hline $\mathrm{CO}_{3}$ & -0.286 & -0.179 & -0.068 & 1.000 & -0.292 \\
\hline $\mathrm{Cl}$ & 0.395 & 0.493 & 0.495 & -0.292 & 1.000 \\
\hline
\end{tabular}

Table 2d: Fourth-step correlation

\begin{tabular}{c|c|c|c|c}
\hline & $\mathbf{C a}-\mathrm{HCO}_{3}-\mathrm{SO}_{4}-\mathrm{Mg}$ & $\mathbf{N a}+\mathrm{K}$ & $\mathbf{C O}_{3}$ & $\mathbf{C l}$ \\
\hline $\mathrm{Ca}-\mathrm{HCO}_{3}-\mathrm{SO}_{4}$ & 1.000 & 0.4745 & -0.2325 & 0.444 \\
\hline $\mathbf{N a}+\mathrm{K}$ & $\mathbf{0 . 4 7 4 5}$ & 1.000 & $\mathbf{- 0 . 0 6 8}$ & $\mathbf{0 . 4 9 5}$ \\
\hline $\mathbf{C O}_{3}$ & -0.2325 & -0.068 & 1.000 & -0.292 \\
\hline $\mathrm{Cl}$ & 0.444 & $\mathbf{0 . 4 9 5}$ & -0.292 & 1.000 \\
\hline
\end{tabular}

Table 2e: Fifth-step correlation matrix

\begin{tabular}{c|c|c|c}
\hline & $\begin{array}{c}\mathrm{Ca}^{-\mathrm{HCO}_{3}-\mathrm{SO}_{\mathbf{4}}-} \\
\mathbf{M g}\end{array}$ & $\mathbf{N a}+\mathrm{K}-\mathrm{Cl}$ & $\mathbf{C O}_{\mathbf{3}}$ \\
\hline $\begin{array}{c}\mathrm{Ca}-\mathrm{HCO}_{\mathbf{3}}- \\
\mathrm{SO}_{\mathbf{4}}\end{array}$ & 1.000 & $\mathbf{0 . 4 5 9 2 5}$ & -0.2325 \\
\hline $\mathrm{Na}+\mathrm{K}-\mathrm{Cl}$ & $\mathbf{0 . 4 5 9 2 5}$ & 1.000 & -0.18 \\
\hline $\mathrm{CO}_{\mathbf{3}}$ & -0.2325 & -0.18 & 1.000 \\
\hline
\end{tabular}

Table 2f: Sixth-step correlation matrix

\begin{tabular}{c|c|c}
\hline & $\begin{array}{c}\mathrm{Ca}-\mathrm{HCO}_{3}-\mathrm{SO}_{4}-\mathrm{Mg}- \\
\mathrm{Na}+\mathrm{K}-\mathrm{Cl}\end{array}$ & $\mathbf{C O}_{3}$ \\
\hline $\begin{array}{c}\mathrm{Ca}-\mathrm{HCO}_{3}-\mathrm{SO}_{4}-- \\
\mathrm{Na}+\mathrm{K}-\mathrm{Cl}\end{array}$ & 1.000 & - \\
\hline $\mathrm{CO}_{3}$ & -0.20625 & 0.20625 \\
\hline
\end{tabular}




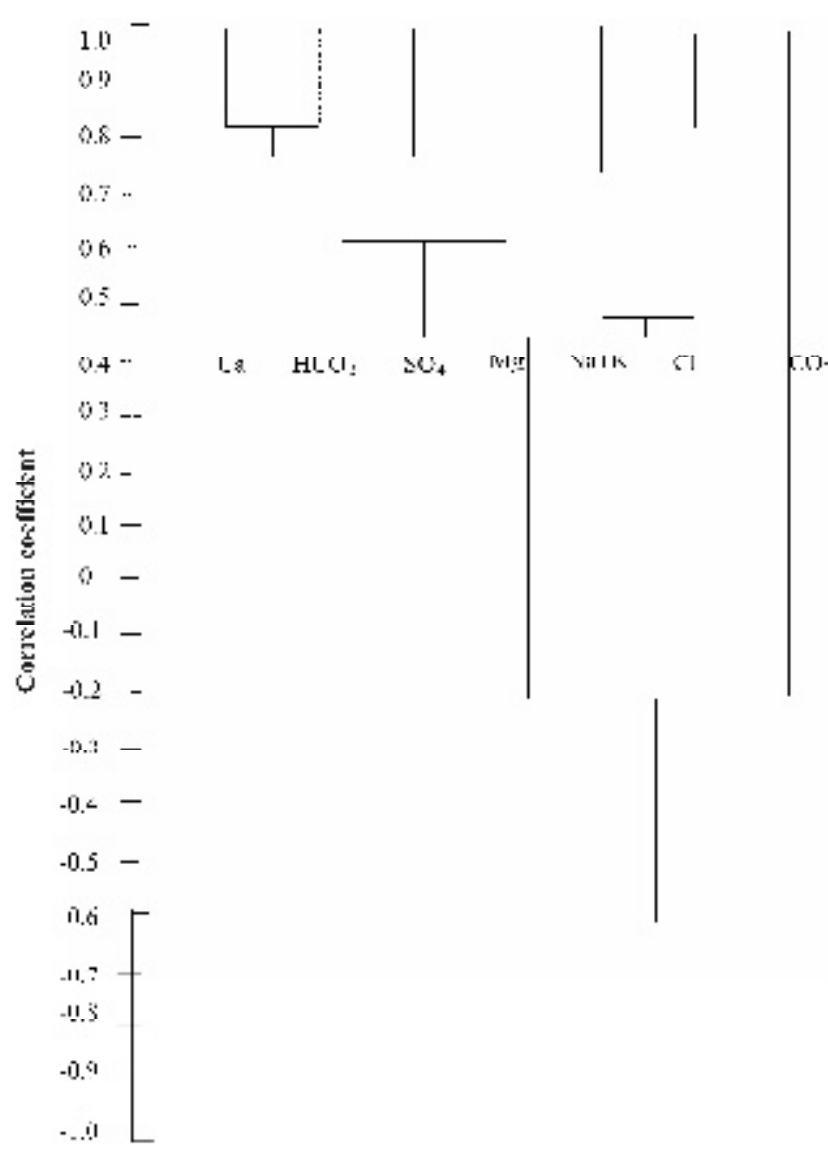

Fig. 6: Dendrogram showing various clusters

correlated value in each column of the matrix was identified (Table 2a). Next the constituent showing similar highest correlation values were then clustered. In the present study, $\mathrm{Ca}^{2+}-\mathrm{HCO}_{3}{ }^{-}$was mutually clustered at the very first stage. The new correlation coefficients between $\mathrm{Ca}^{2+}-\mathrm{HCO}_{3}{ }^{-}$cluster and the remaining independent constituents were recalculated by the arithmetic averaging method. The rest of the correlation coefficients of individual constituents were retained as such in Table $2 \mathrm{~b} . \mathrm{SO}_{4}{ }^{2-}$ and $\mathrm{Ca}^{2+}-\mathrm{HCO}_{3}^{-}$were also clustered considering $\mathrm{Ca}^{2+}-\mathrm{HCO}_{3}{ }^{-}$as a single element by the arithmetic averaging method. New correlation coefficients between $\mathrm{Ca}^{2+}-\mathrm{HCO}_{3}{ }^{-}-\mathrm{SO}_{4}{ }^{2-}$ cluster and independent constituents were recalculated by the arithmetic averaging procedure (Table $2 \mathrm{c}$ ). In the subsequent step, $\mathrm{Mg}^{2+}$ was clustered with $\mathrm{Ca}^{2+}-\mathrm{HCO}_{3}^{-}-\mathrm{SO}_{4}{ }^{2-}$ (Table $\left.2 \mathrm{~d}\right)$. In the next step, $\mathrm{Cl}^{-}$was clustered with $\mathrm{Na}^{+}+\mathrm{K}^{+}$(Table 2e). Finally, $\mathrm{Ca}^{2+}-\mathrm{HCO}_{3}{ }^{-}-\mathrm{SO}_{4}{ }^{2-}-\mathrm{Mg} 2+$ and $\mathrm{Na}^{+}+\mathrm{K}^{+}-\mathrm{Cl}^{-}$clusters were grouped. At the end, $\mathrm{Ca}^{2+}-\mathrm{HCO}_{3}{ }^{-}-\mathrm{SO}_{4}{ }^{2-}-\mathrm{Mg}^{2+}$ and $\mathrm{Na}^{+}+\mathrm{K}^{+}-$ $\mathrm{Cl}^{-}$and $\mathrm{CO}_{3}{ }^{2-}$ were clustered (Table 2f). A stepwise dendrogram was constructed (Fig. 6) according to the step correlation matrices.

The cluster of $\mathrm{Ca}^{2+}-\mathrm{HCO}_{3}{ }^{-}$shows a significantly high correlation coefficient of 0.82 . This, in turn, has a correlation coefficient of 0.77 with $\mathrm{SO}_{4}{ }^{2-}$. Next, the $\mathrm{Ca}^{2+}-\mathrm{HCO}_{3}{ }^{-}-\mathrm{SO}_{4}{ }^{2}$ cluster has a correlation coefficient value of 0.62 with $\mathrm{Mg}^{+}$.
Similarly, the $\mathrm{Na}^{+}+\mathrm{K}^{+}-\mathrm{Cl}^{-}$cluster exhibits a correlation coefficient of 0.49 with the above cluster. The $\mathrm{Ca}^{2+}-\mathrm{HCO}_{3}^{-}-$ $\mathrm{SO}_{4}^{2-}-\mathrm{Mg}^{2+}$ cluster is linked with the $\mathrm{Na}^{+}+\mathrm{K}^{+}-\mathrm{Cl}^{-}$cluster with a correlation coefficient of 0.45 . As compared to the highest correlation coefficient (0.822), $\mathrm{CO}_{3}^{2-}$ displays a marked lower coefficient of 0.20625 with the last cluster.

The cluster analysis suggests that two main interrelated types of chemical constituents are responsible for the hydrogeochemical variation in the quality of groundwater. From the dendrogram, following types of groundwater were identified.

Type I: $\mathrm{Ca}^{2+}-\mathrm{HCO}_{3}{ }^{-}-\mathrm{SO}_{4}{ }^{2-}-\mathrm{Mg} 2+$ or calcium-rich water.

Type II: $\mathrm{Na}^{+}+\mathrm{K}^{+}-\mathrm{Cl}^{-}$or sodium-rich water

\section{Type I water}

In the $\mathrm{Ca}^{2+}-\mathrm{HCO}_{3}{ }^{-}-\mathrm{SO}_{4}{ }^{2-}-\mathrm{Mg} 2+$ cluster, $\mathrm{Ca}^{2+}$ is the dominant cation, which has a high correlation coefficient with the bicarbonate. Further, $\mathrm{SO}_{4}^{2-}$ and $\mathrm{Mg}^{2+}$ have an intermediate value of correlation coefficient with sodium bicarbonate. Hence, there is an increase in $\mathrm{pH}$ and decrease in acidity in such waters.

\section{Type II water}

The $\mathrm{Na}^{+}+\mathrm{K}^{+}$cluster is correlated positively with $\mathrm{Cl}^{-}$. As granites and gneisses are the predominant rocks of the area, there is an abundance of Na-rich plagioclase, which is easily dissolved in water. The $\mathrm{Na}^{+}$and $\mathrm{Cl}^{-}$ions are dominant in the groundwater, leading to a higher salinity (i.e. TDS).

\section{CONCLUSIONS}

In the Jamankira area, the rock type controls primarily the chemical properties of groundwater, which is mostly characterised by $\mathrm{Ca}^{2+}-\mathrm{HCO}_{3}^{-}$type. The groundwater samples of the study area have a sodium percentage value of 10.06 to 37.13 epm (except at Phulkusum where it is $>40$ epm); hence for irrigation purposes they are excellent to good. The water of Phulkusum comes under the permissible category. The U.S. salinity diagram indicates that $26.7 \%$ of water samples fall in $\mathrm{C}_{1} \mathrm{~S}_{1}$ class, $60 \%$ of them fall in $\mathrm{C}_{2} \mathrm{~S}_{1}$ class, and remaining $13.3 \%$ of them lie in $\mathrm{C}_{3} \mathrm{~S}_{1}$ class. From Trilinear Piper's diagram, three distinct hydrochemical facies $\left(\mathrm{Na}^{+}-\mathrm{K}^{+}-\mathrm{Cl}^{-}-\mathrm{SO}_{4}{ }^{2-}\right.$, $\mathrm{Ca}^{2+}-\mathrm{Mg}^{-}-\mathrm{Cl}^{-}-\mathrm{SO}_{4}^{2-}$, and $\left.\mathrm{Na}^{+}-\mathrm{K}^{+}-\mathrm{HCO}_{3}^{-}\right)$are identified. Based on the cluster analysis, the groundwater was classified into Type I (calcium-rich) and Type II (sodium-rich) waters.

\section{REFERENCES}

Davis, J. C., 1973, Statistics and data analysis in geology, John Wiley \& Sons, Inc., New York, pp. 330-333.

Eaton, F. M., 1950, Boron in soils and irrigation water and its effect on plants, with particular reference to the San Joaquin Valley of California, U. S. Dept. Agricul. Tech. Bull. Washington D. C., v. 448(131), 935 p.

Geological Survey of India, 1979, Geological Survey of India map printing division, Hyderabad, India, F-44R. 
Parks, J. M., 1966, Cluster analysis applied to multivariate geological problems. Jour. Geol., v. 74, pp. 703-715.

Piper, A. M., 1944, A graphical procedure in the geochemical interpretation of water analysis, Trans. Amer. Geophys. Union, v. 15 , pp 14-923.

Richards, L. A. (Ed.), 1954, Diagnosis and improvement of saline and alkali soils, Agricul. Handbook 60, U. S. Dept. Agricul., Washington, D. C., 160 p.
Wadia, D. N., 1957, Geology of India ( $3^{\text {rd }}$ Edition) McMillan, London. $536 \mathrm{p}$.

Wilcox, L. V., 1948, The quality of water for irrigation, U.S. Dept. Agri. Tech. Bull. Washington D. C., 40 p. 